\title{
Correction to: Long noncoding RNA TUG1 facilitates osteogenic differentiation of periodontal ligament stem cells via interacting with Lin $28 \mathrm{~A}$
}

Qin He $\mathbb{C}^{1,2}$, Shuangyan Yang ${ }^{1,2}$, Xiuge Gu ${ }^{1,2}$, Mengying $\mathrm{Li}^{1,2}$, Chunling Wang ${ }^{1,2}$ and Fulan Wei $\mathbb{C}^{1,2}$

Correction to: Cell Death Disease 9, 455 (2018); https://doi.org/10.1038/s41419-018-0484-2; published online 19 April 2018.

Since publication of this article, the authors found a mistake in the drawing Fig. 5e. After careful checking of all original data, the authors discovered that they had submitted the wrong composite Fig. 5e. The correct Fig. 5 is included below.

The authors apologise for any inconvenience caused.

Correspondence: Chunling Wang (wangchl@sdu.edu.cn) or Fulan Wei

(weifl@sdu.edu.cn)

'Department of Orthodontics, School of Stomatology, Shandong University,

Jinan, People's Republic of China

${ }^{2}$ Shandong Provincial Key Laboratory of Oral Tissue Regeneration, School of

Stomatology, Shandong University, Jinan, People's Republic of China

(c) The Author(s) 2018

(c) (i) Open Access This article is licensed under a Creative Commons Attribution 4.0 International License, which permits use, sharing, adaptation, distribution and reproduction BY in any medium or format, as long as you give appropriate credit to the original author(s) and the source, provide a link to the Creative Commons license, and indicate if changes were made. The images or other third party material in this article are included in the article's Creative Commons license, unless indicated otherwise in a credit line to the material. If material is not included in the article's Creative Commons license and your intended use is not permitted by statutory regulation or exceeds the permitted use, you will need to obtain permission directly from the copyright holder. To view a copy of this license, visit http://creativecommons.org/licenses/by/4.0/. 


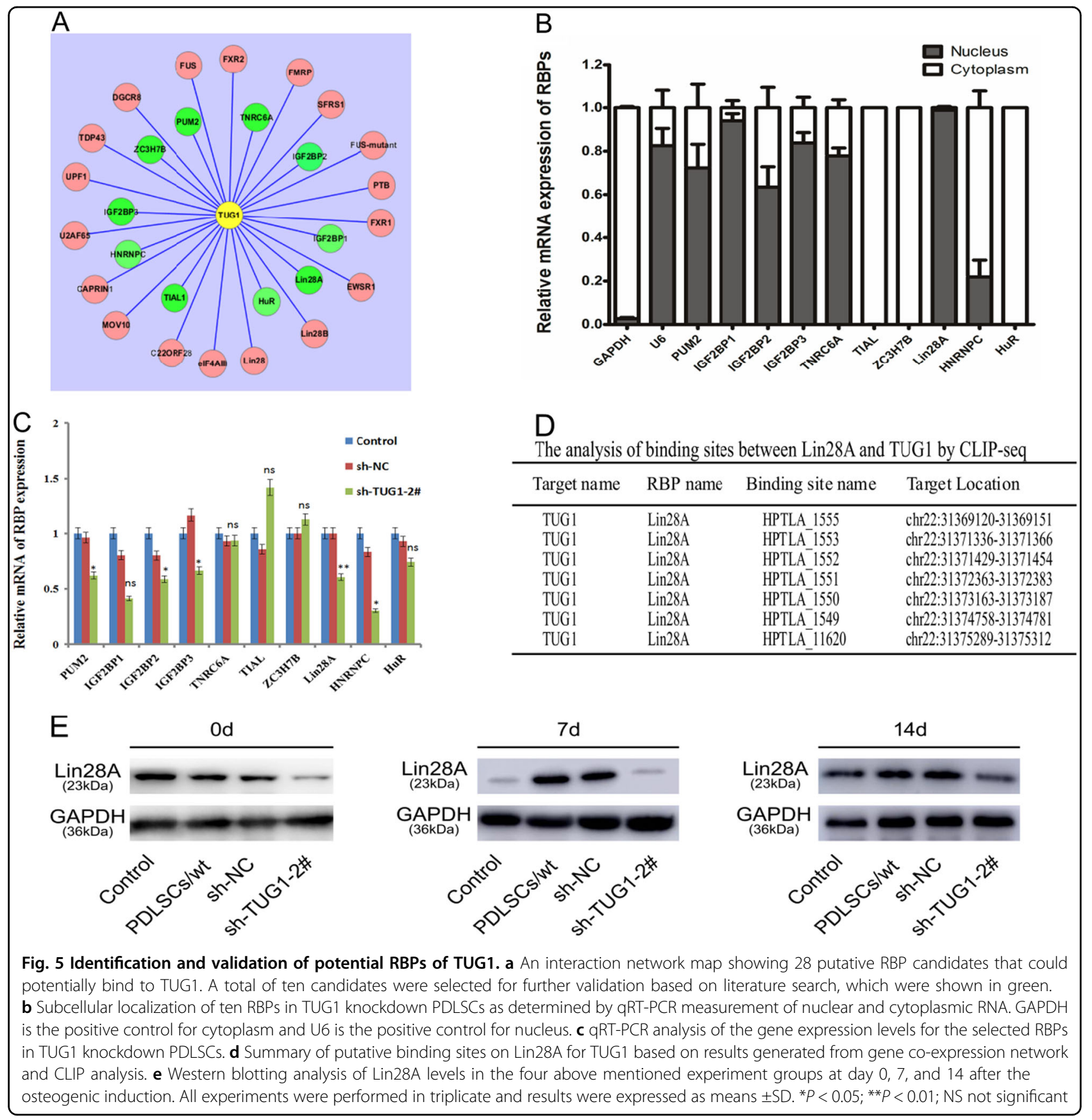

